\title{
SCNN Based Electrical Characteristics of Solar Photovoltaic Cell Model
}

\author{
Bambang Purwahyudi ${ }^{1}$, Kuspijani ${ }^{2}$, Ahmadi $^{3}$ \\ ${ }^{1,2,3}$ Departement of Electrical Engineering, University of Bhayangkara, Surabaya, Indonesia
}

\begin{abstract}
Article Info
Article history:

Received Mar 14, 2017

Revised Jun 23, 2017

Accepted Jul 18, 2017

\section{Keyword:}

Solar photovoltaic cell Electrical characteristics Self constructing neural network Current-voltage characteristics Power-voltage characteristics

ABSTRACT

Solar photovoltaic (PV) cell is one of the renewable energy sources and a main component of PV power systems. The design of PV power systems requires accurately its electrical output characteristics. The electrical characteristics of solar PV cell consist of I-V and P-V characteristics. They depend on the parameters of PV cell such as short circuit current, open circuit voltage and maximum power. Solar PV cell model can be described through an equivalent circuit including a current source, a diode, a series resistor and a shunt resistor. In this paper, the development solar PV cell model is built by using self constructing neural network (SCNN) methods. This SCNN technique is used to improve the accuracy of the electrical characteristic of solar PV cell model. SCNN solar PV cell model have three inputs and two outputs. They are respectively solar radiation, temperature, series resistance, current and power. The effectiveness of SCNN technique is verified using simulation results based on different physical and environmental conditions. Simulations are conducted by the change of the solar irradiation, temperature and series resistance. Simulation results show SCNN model can yield the I-V and P-V characteristics according to the characteristics of solar PV cell.
\end{abstract}

Copyright @ 2017 Institute of Advanced Engineering and Science. All rights reserved.

\section{Corresponding Author:}

Bambang Purwahyudi, Departement of Electrical Engineering, University of Bhayangkara Surabaya, Jl. A. Yani 114, Surabaya 60321, Indonesia.

Email: bmp_pur@ubhara.ac.id

\section{INTRODUCTION}

Solar energy is a promising alternative energy source due to energy crisis and environmental issues such as global warming effect and pollution. Photovoltaic (PV) power generation is one of the more important renewable sources since it had great many merits such as clean, free maintenance and no noise. However, PV generation system has two disadvantages that is the low conversion efficiency in electric power generation and the changes in several weather conditions. In addition, the electrical characteristic of solar PV cell is nonlinear which is affected by solar radiation $(S)$, atmosphere temperature $(T)$ and series resistance $\left(R_{s}\right)$. The electrical characteristics of solar PV cell consist of I-V and P-V characteristics. Solar PV cell is built from a current source parallel with diode $(D)$, shunt resistance $\left(R_{s h}\right)$ and series resistance $\left(R_{s}\right)[1]-[6]$.

The applications of artificial intelligent in solar PV generation system have been proposed [6]-[9]. Neural network (NN) is one of the popular artificial intelligents. Advantages of NN are easy in training and simple architecture. However, NN has several drawbacks such as in determining number hidden layers and number neurons in hidden layer [10]-[16]. These matters can be solved by self constructing neural network (SCNN). SCNN can automatically construct number of neurons in hidden layer and number of hidden layers [11]-[13]. In this paper, SCNN is used to create solar PV cell model. This SCNN technique improves the accuracy of electrical characteristic behavior of solar PV cell. The effectiveness of SCNN method is evaluated using simulation results based on varying solar radiation, temperature and series resistance. This 
paper is organized as follows: the solar PV cell model is described in Section 2; Section 3 shows the principal of SCNN; Section 4 shows the design of SCNN solar PV cell model; the effectiveness of the proposed SCNN method is clarified through a MATLAB/ SIMULINK simulation which is presented in Section 5; the conclusion, and references list end this paper.

\section{SOLAR PHOTOVOLTAIC CELL MODEL}

The main component of solar power generation systems is photovoltaic (PV). PV cell or known as the solar panels are made from semiconductor materials such as silicon and germanium. When the sunlight reaches the PV cell, the silicon atom will release electrons. The electrons will flow making the electric circuit, so that electrical energy can be generated. This PV cell can be connected in series or parallel to produce the desired voltage and current.

The performances of the PV cell depend on the intensity of the sunlight. Weather conditions such as clouds and fog affect solar energy received by PV cell, so that they will influence the performance of the PV cell. The simple equivalent circuit of solar PV cell is a current source parallel with a diode. Solar cell model is shown in Figure 1. The solar PV cell model consists of a current source $\left(\mathrm{I}_{\mathrm{ph}}\right)$, a diode (D), a shunt resistance $\left(R_{s h}\right)$, and a series resistance $\left(R_{s}\right)[1]-[6]$.

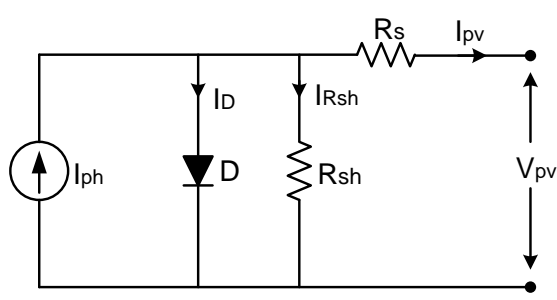

Figure 1. Equivalent circuit of solar PV cell

Diode determines the I-V characteristics of PV cell. Current source output is proportional to the light falling on the PV cell. Open circuit voltage increases as the logarithm according Shockley diode equation that describes the interdependence between the voltage and current in PV cell as shown in equation (1) and equation (2).

$$
\begin{aligned}
& I=I_{P V}-I_{0}\left(e^{q U / k T}-1\right) \\
& V=\frac{k T}{q} \ln \left(1-\frac{I-I_{P V}}{I_{O}}\right)
\end{aligned}
$$

where $k, T, q, V, I_{0}$ and $I_{P V}$ are respectively Boltzman constant $\left(1.3806 \times 10^{-23} \mathrm{~J} / \mathrm{K}\right)$, temperature $\left({ }^{0} \mathrm{~K}\right)$, electron charge $\left(1.6021 \times 10^{-19} \mathrm{C}\right)$, the PV cell terminal voltage, the reverse saturation current and the light generated current. From equation (1) and equation (2) can be determined the characteristics of the solar panel. That is the I-V characteristics and the P-V characteristics. These characteristics of the PV cell are non-linear and more influenced by the intensity of solar radiation and temperature of PV cell surface [1]-[6].

\section{PRINCIPAL OF SELF CONSTRUCTING NEURAL NETWORK}

Artificial neural network (ANN) is a machine that the work principle emulates the human brain. ANN has the abilities of learning and generalization. Structure of ANN consists of three layers, an input layer, one or more hidden layers, and an output layer. Design of ANN is conducted in two steps. First step is determining of its structure consist of the number of neurons in hidden layers and the number of hidden layers. Second step is determining of the desired error value and maximum learning epoch. Determining of the number of neurons in the hidden layer and the number of hidden layers is generally done trial and error [10]-[16]. The disadvantages of ANN can be solved by Self Constructing Neural Network (SCNN) method.

Basic structure of self constructing neural network (SCNN) is artificial neural network (ANN). The different between both methods is in determining the structures. SCNN can automatically arrange number of neurons in hidden layer and number of hidden layer. Structure of SCNN is shown in Figure 2 [11]-[13]. 


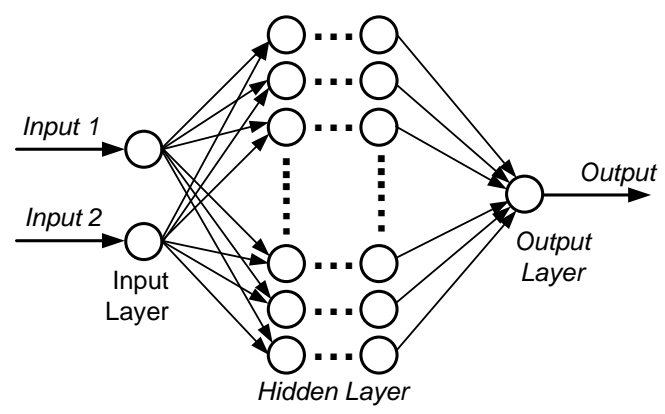

Figure 2. Structure of SCNN

The determining process of SCNN structure can be described using flowchart shown in Figure 3. The number of neuron in hidden layers will automatically increase when error is greater than maximum error. And also, the number of hidden layers will increase when maximum error is smaller than error and the number of neurons in hidden layer is smaller than maximum neurons.

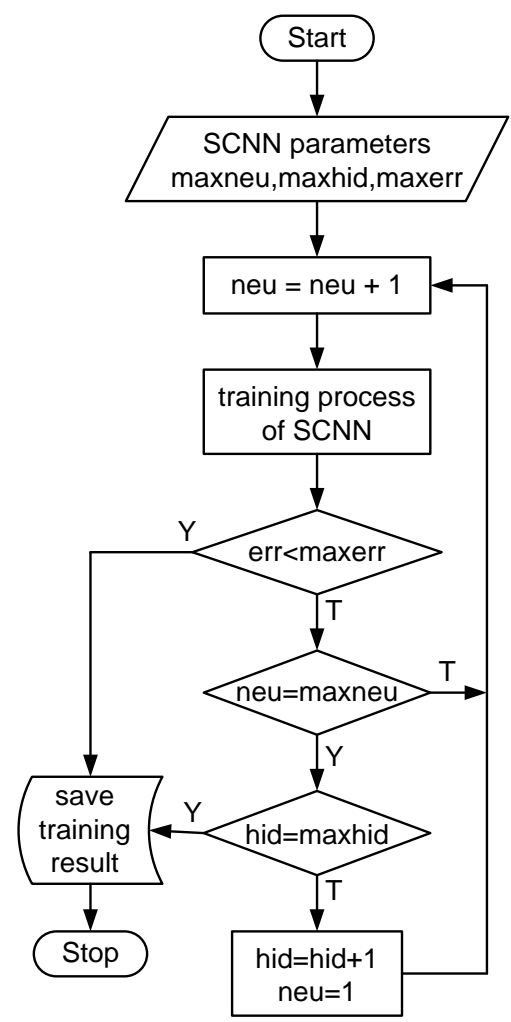

Figure 3. Flowchart of SCNN process

\section{DESIGN OF SCNN PHOTOVOLTAIC (PV) CELL MODEL}

SCNN solar PV model is designed to imitate electrical characteristic behavior of solar PV cell. SCNN solar PV model is shown in Figure 4. SCNN solar PV model have three inputs and two outputs such as solar radiation $(S)$, cell temperature $(T)$, series resistor $\left(R_{s}\right)$, cell current $\left(I_{p v}\right)$ and cell power $\left(P_{p v}\right)$, respectively. 


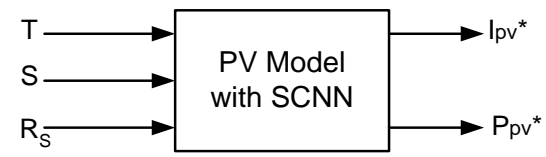

Figure 4. SCNN solar PV model

SCNN solar PV model is based on input and output values of mathematical model of solar PV cell. This SCNN solar PV model must be trained before being used as solar PV model. The training process of SCNN method can be seen in Figure 5. Training algorithm of SCNN solar PV cell model uses backpropagation. Data training of SCNN is taken from mathematical model of solar PV cell.

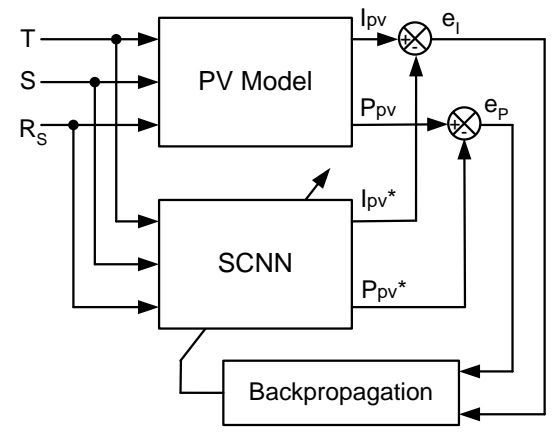

Figure 5. Training process of SCNN solar PV cell

\section{SIMULATION RESULT AND DISCUSSION}

The effectiveness of the proposed SCNN PV cell model is tested by a SIMULINK/MATLAB simulation. Therefore, SCNN PV cell model is compared with the mathematical model of PV model based on change of operating conditions such as solar radiation $(S)$, temperature $(T)$ and series resistance $\left(R_{S}\right)$. The parameters of solar PV cell and the parameters of SCNN employed in simulation are shown in Table 1 can be seen in Table 2.

Table 1. Electrical specification of the solar PV module

\begin{tabular}{lc}
\hline \multicolumn{1}{c}{ Parameter } & Value \\
\hline Maximum Power $\left(\mathrm{P}_{\mathrm{PV}}\right)$ & $60 \mathrm{~W}$ \\
Voltage at Max. Power $\left(\mathrm{V}_{\mathrm{MP}}\right)$ & $17.1 \mathrm{~V}$ \\
Current at Max. Power (I $\left.\mathrm{I}_{\mathrm{MP}}\right)$ & $3.4 \mathrm{~A}$ \\
Open Circuit Voltage (VOC) & $21.1 \mathrm{~V}$ \\
Short Circuit Current (ISC) & $3.8 \mathrm{~A}$ \\
\hline
\end{tabular}

Table 2. The parameters of SCNN

\begin{tabular}{lc}
\hline \multicolumn{1}{c}{ Parameter } & Value \\
\hline Maximum Hiden Layers & 5 \\
Maximum Neurons in Hidden Layer & 20 \\
Maximum Error & $1 \mathrm{e}^{-4}$ \\
Maximum Epoch & 1000 \\
\hline
\end{tabular}

SCNN must be trained before being used as solar PV cell model. The training process provides the optimal structure of SCNN. The training results of SCNN solar PV model for I-V characteristics and P-V characteristics are shown in Table 3. The performance of SCNN during the training process can be seen in Figure 6 and Figure 7. 
Table 3. The training results of SCNN solar PV model

\begin{tabular}{lcc}
\hline \multicolumn{1}{c}{ Parameter } & I-V Characteristic & P-V Characteristic \\
\hline Number of Hiden Layers & 1 & 3 \\
Number of Neurons in Hidden Layer & 9 & 13 \\
Epochs & 215 & 246 \\
\hline
\end{tabular}

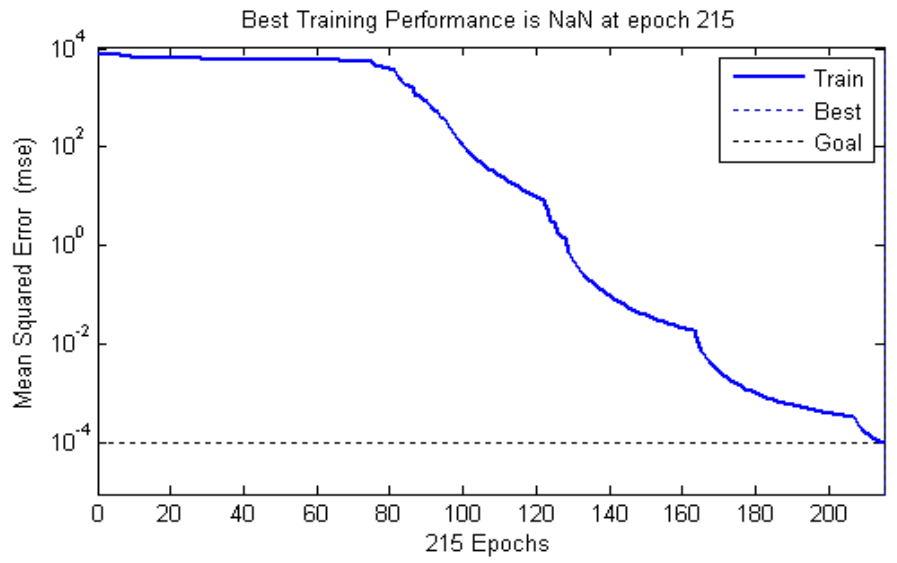

Figure 6. Performance of SCNN solar PV model for the I-V characteristics

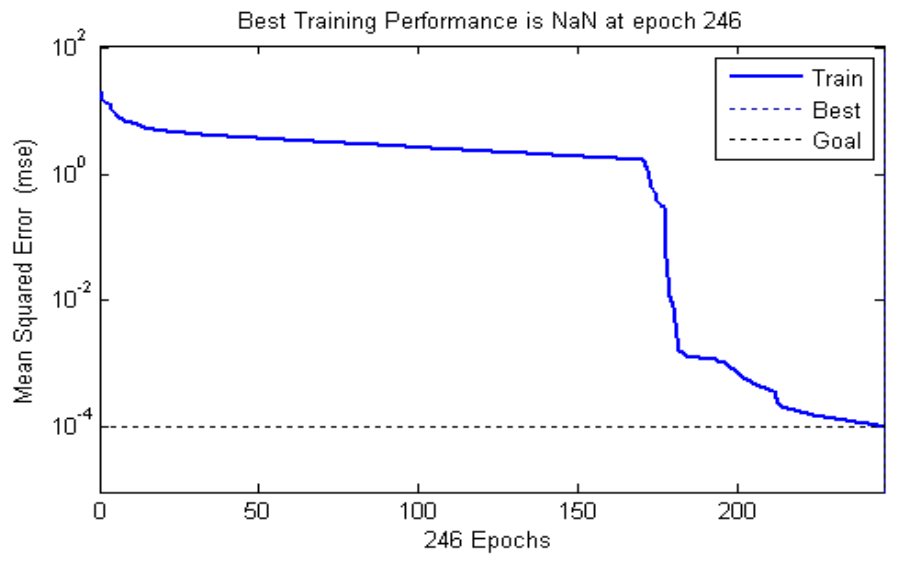

Figure 7. Performance of SCNN solar PV model for the P-V characteristics

\subsection{Influences of Solar Radiation Variation}

The variations of solar radiation in simulation process are $1 \mathrm{~kW} / \mathrm{m}^{2}, 0.8 \mathrm{~kW} / \mathrm{m}^{2}, 0.6 \mathrm{~kW} / \mathrm{m}^{2}, 0.4$ $\mathrm{kW} / \mathrm{m}^{2}$ and $0.2 \mathrm{~kW} / \mathrm{m}^{2}$, respectively. Figure 8 show the I-V characteristics for variation of solar radiations. The simulation results of the proposed SCNN model and the mathematical model of the solar PV cell are shown by the circular (o) and solid line. From Figure 8 can be seen that short circuit current and open circuit voltage of solar photovoltaic cell will increase when solar radiation increase.

Figure 9 show P-V characteristics for solar radiation variation. The simulation of the proposed SCNN model and the mathematical model of the solar PV cell are shown by the circular (o) and solid line. Figure 9 show that maximum power and open circuit voltage of solar photovoltaic cell will increase when solar radiation increase. 


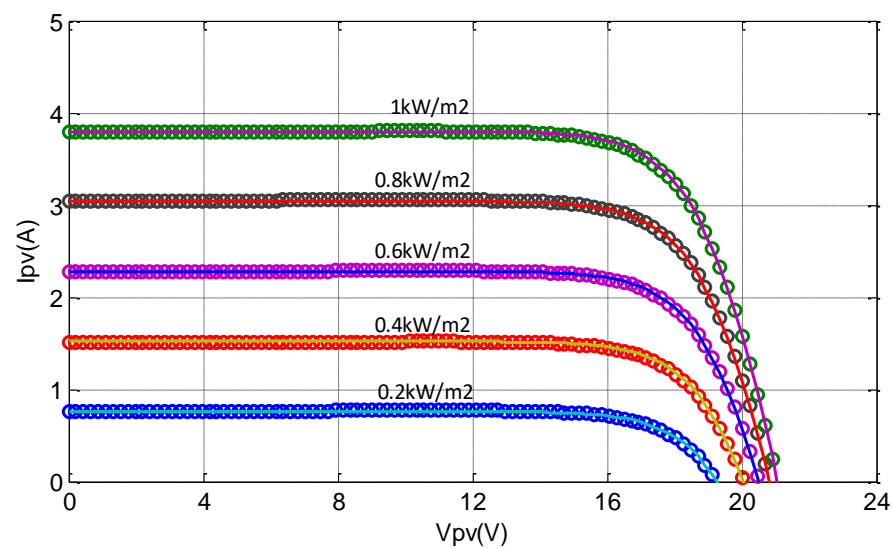

Figure 8. The I-V characteristics for variation of solar radiation

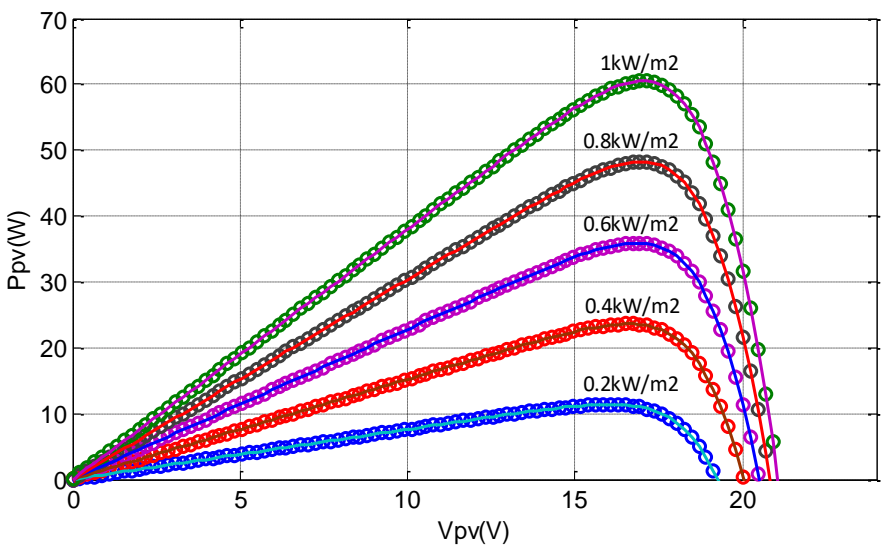

Figure 9. The P-V characteristics for variation of solar radiation

\subsection{Influences of Temperature Variation}

The temperature variations are respectively $0{ }^{\circ} \mathrm{C}, 25{ }^{\circ} \mathrm{C}, 50{ }^{\circ} \mathrm{C}, 75{ }^{\circ} \mathrm{C}$ and $100{ }^{\circ} \mathrm{C}$. Figure 10 show I$\mathrm{V}$ characteristics for variation of temperature. The simulation of the proposed SCNN model and the mathematical model of the solar PV cell are shown by the circular (o) and solid line. Short circuit current of solar photovoltaic cell will increase when cell temperature increase. However, open circuit voltage of solar photovoltaic cell will decrease when temperature increase.

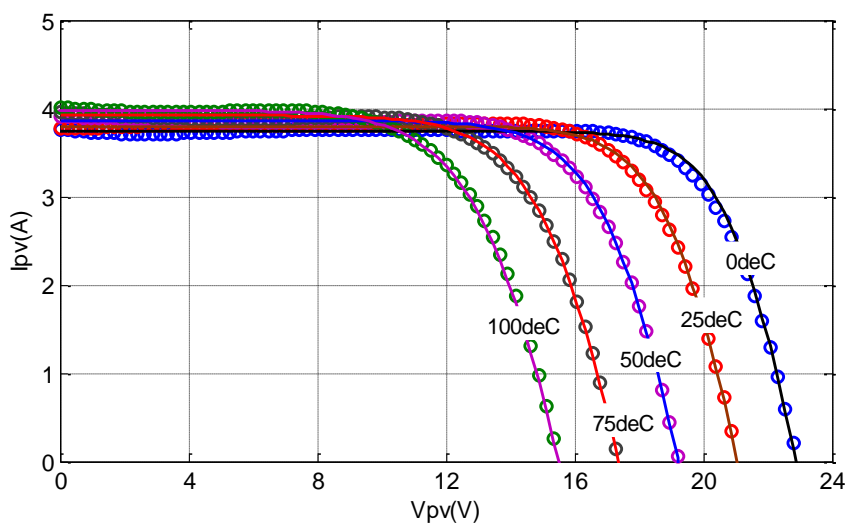

Figure 10. The I-V characteristics for variation of cell temperature 
Figure 11 show the $\mathrm{P}-\mathrm{V}$ characteristics for variation of cell temperature. The simulation of the proposed SCNN model and the mathematical model of the solar PV cell are shown by the circular (o) and solid line. Maximum power and open circuit voltage of solar photovoltaic cell will decrease when temperature increase.

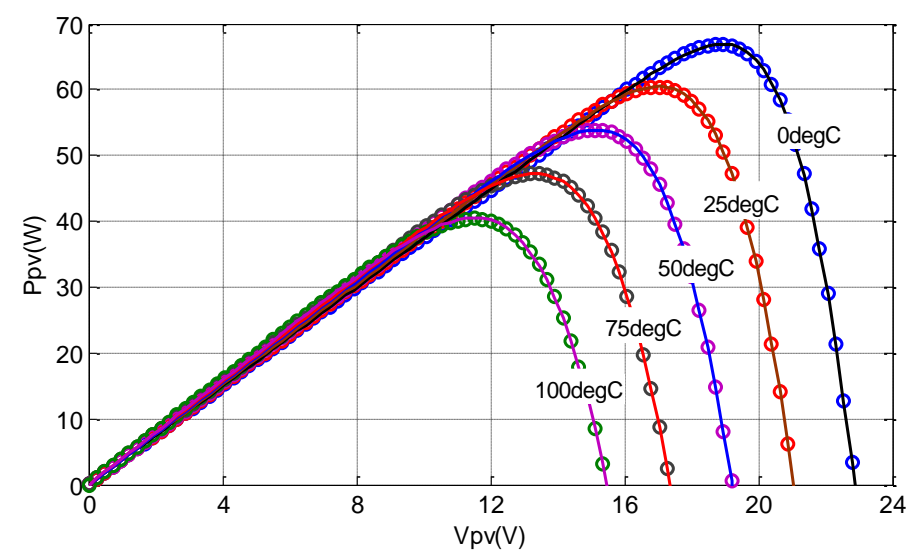

Figure 11. The P-V characteristics for variation of cell temperature

\subsection{Influences of Series Resistance Variation}

In the simulation, the changes of series resistance are $0 \Omega, 5 \mathrm{~m} \Omega, 10 \mathrm{~m} \Omega, 15 \mathrm{~m} \Omega$ and $20 \mathrm{~m} \Omega$, respectively. Figure 12 show the I-V characteristics for variation of series resistor. The simulation of the proposed SCNN model and the mathematical model of the solar PV cell are shown by the circular (o) and solid line. Short circuit current and open circuit voltage of solar photovoltaic cell will not change when there are variation of series resistor. The variation of series resistance causes the slope angle of the I-V characteristics.

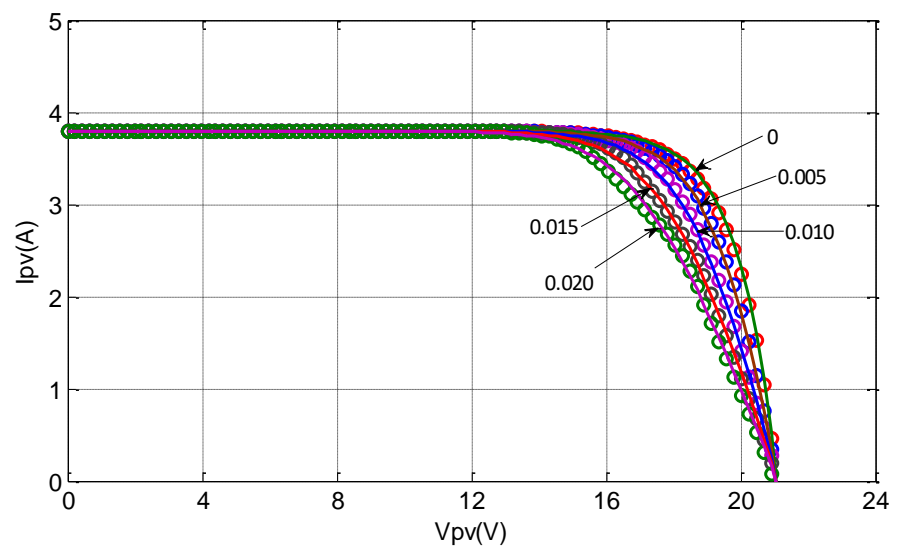

Figure 12. The I-V characteristics for variation of series resistance

Figure 13 show the P-V characteristics for change of series resistor. Maximum power of solar photovoltaic cell will decrease series resistance increase. However, open circuit voltage of solar photovoltaic cell still constant. 


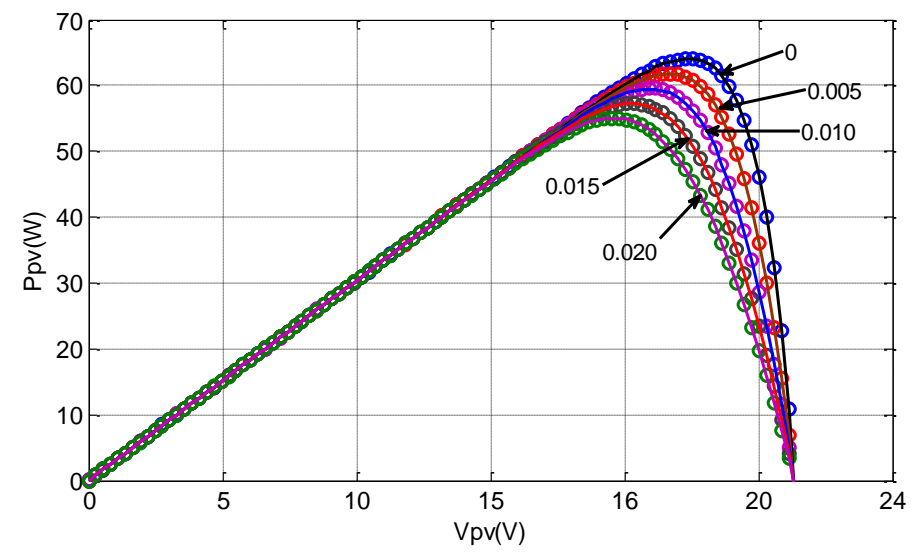

Figure 13. The P-V characteristics for variation of series resistance

\section{CONCLUSION}

Self constructing neural network (SCNN) based electrical characteristic of solar photovoltaic cell model has been presented and discussed. SCCN technique is used to improve accurately the electrical characteristic of solar photovoltaic cell model. The effectiveness of SCCN technique is clarified by simulation and compared with matematical model of solar PV model. Simulation is done by the change of operating conditions such as the solar radiation $(S)$, temperature $(T)$ and series resistance $\left(R_{s}\right)$. Simulation results show that SCNN solar PV cell model can produce the I-V and P-V characteristics according to the characteristics of solar PV cell.

\section{ACKNOWLEDGEMENTS}

This paper is supported and funded by Ministry of Research, Technology and Higher Education Republic of Indonesia through Coordination of Public Higher Education, Region VII East Java in 2016.

\section{REFERENCES}

[1] R. Chenni, et al., "A Detailed Modelling Method for Photovoltaic Cells," Energy, Elsevier, vol/issue: 32(9), pp. 1724-1730, 2007.

[2] J. S. Kumari and C. S. Babu, "Mathematical Modelling and Simulation of Photovoltaic Cell using Matlab-Simulink Environment," International Journal of Electrical an Computer Engineering, vol/issue: 2(1), pp. 26-34, 2012.

[3] J. Bikaneria, et al., "Modeling and simulation of PV cell using one-diode model," International Journal of Scientific and Research Publications, vol/issue: 3(10), pp. 1-4, 2013.

[4] S. Shongwe and M. Hanif, "Comparative analysis of different single-diode PV modeling methods," IEEE Journal of Photovoltaic, vol/issue: 5(3), pp. 938-946, 2015.

[5] E. Batzelis, et al., "Direct MPP calculation in terms of the single-diode PV model parameter," IEEE Transaction on Energy Conversion, vol/issue: 30(1), pp. 226-236, 2015.

[6] F. Bonanno, et al., "A radial basis fuction neural network based approach for the electrical characteristics estimation of a photovoltaic module," Applied Energy, vol. 97, pp. 956-961, 2012.

[7] N. Mohammad, et al., "Improved Solar Photovoltaic Array Model with FLC Based Maximum Power Point Tracking," International Journal of Electrical and Computer Engineering, vol/issue: 2(6), pp. 717-729, 2012.

[8] S. Karthika, et al., "Fuzzy Logic Based Maximum Power Point Tracking Design for $10 \mathrm{~kW}$ Solar Photovoltaic System with Different Membership Function," International Journal of Electrical, Computer, Energetic, Electronic and Communication Engineering, vol/issue: 8(6), pp. 1015-1019, 2014.

[9] A. E. Filali, et al., "Modeling and simulation of photovoltaic system employing perturb and obsere MPPT algorithm and fuzzy logic control," Journal of Theoretical and Applied Information Technology (JATIT), vol/issue: 89(2), pp. 470-475, 2016.

[10] B. Purwahyudi, et al., "Perbandingan Neural Network (NN) Observer dan Neural Network - Genetic Algorithm (NN-GA) Observer untuk Estimasi Kecepatan Motor Induksi," Seminar Nasional Aplikasi Teknologi Informasi 2005 (SNATI 2005), Yogyakarta, Indonesia, pp. C71-C77, 2005.

[11] H. C. Lu and M. H. Chang, "Online Speed Control of Permanent Magnet Synchronous Motor Using Self Constructing Recurrent Fuzzy Neural Network," Proceeding of the $7^{\text {th }}$ International Conference on Machine Learning and Cybernetics, Kunming, China, pp. 3857-3862, 2008.

[12] J. S. Lee, et al., "Self Organizing Neural Networks by Construction and Pruning," IEICE Transaction on Information \& System, vol/issue: E87-D(11), pp. 2489-2498, 2004. 
[13] C. F. Hsu, "Intelligent Position Tracking Control for LCM Drive Using Stable Online Self Constructing Recurrent Neural Network Controller with Bound Architecture," Control Engineering Practice, vol. 17, pp. 714-722, 2009.

[14] B. Purwahyudi, et al., "Feed-forword neural network for direct torque control of induction motor," International Journal of Innovative Computing, Information and Control (IJICIC), vol/issue: 7(11), pp. 6135-6145, 2011.

[15] B. Purwahyudi, et al., "RNN based rotor flux and speed estimation of induction motor," International Journal of Power Electrinics and Drive System (IJPEDS), vol/issue: 1(1), pp. 58-64, 2011.

[16] B. Purwahyudi, et al., "Neural network technique for direct torque control of induction motor used in electrically driven marine propeller," International Journal of Academic Research, vol/issue: 3(5), pp. 358-364, 2011.

\section{BIOGRAPHIES OF AUTHORS}

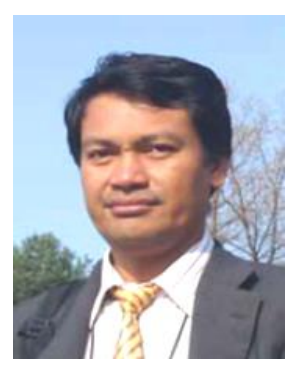

Bambang Purwahyudi received his bachelor, master and doctor degree in electrical engineering from Institut Teknologi Sepuluh Nopember (ITS) Surabaya, Indonesia, in 1995, 2005 and 2013 respectively. He has joined Bhayangkara University of Surabaya, Indonesia, since 2000. His areas of interest are simulation and design of power electronics and drives, power quality, renewable energy, and artificial intelligent application.

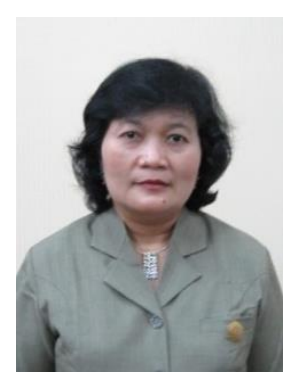

Kuspijani received her bachelor in electrical engineering from Brawijaya University, Malang, Indonesia in 1986 and Master degree in technology management from Institut Teknologi Sepuluh Nopember (ITS) Surabaya in 2010. She has joined Bhayangkara University Surabaya, Indonesia, since 1987. Her research interest on distribution power system, power systems and power system generation.

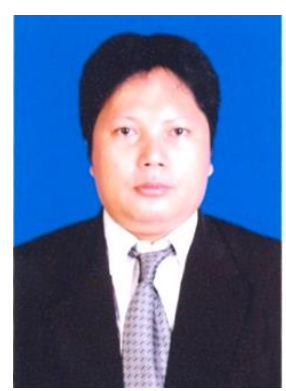

Ahmadi received his bachelor in electrical engineering from Bhayangkara University Surabaya, Indonesia in 2000 and Master degree in control engineering from Institut Teknologi Sepuluh Nopember (ITS) Surabaya in 2014. She has joined Bhayangkara University Surabaya, Indonesia, since 2016. His research interest are on power electronics, industrial control system, artificial intelligent application, and robotic. 